\title{
DOES DIVERSIFICATION STRATEGY PLAY AN EMINENT ROLE IN THE CURRENT TURBULENCE OF DIGITAL ECONOMY: A STRATEGIC APPROACH
}

\author{
Augustinus Nicolaas Hillebrandes Oroh \\ School of Business and Management, Universitas Ciputra, Surabaya, Indonesia
}

ABSTRACT - Most industry players are dubious whether current digital technology is strongly affecting the long traditional demand and supply economy while scholars believe that companies need to have valuable and unique resources, excellent and agile capabilities, and capacity of aligning its core competencies to lead the industry and therefore, sustaining its competitive advantage. Companies are fighting with the aggressive movements by their competitors in the changing markets and facing very dynamic full of surprises environmental turbulence. It is revealed that the Environment Serving Organization concept helps companies to be well prepared in advance and applicable at all turbulence levels when the overall economy is at high uncertainty. By exploring diversification based on Ansoff Growth Matrix and using the regression and mediation models, this is one of the first papers that investigates Environmental Turbulence level as a probable mediator in the intense relationship between diversification strategy and strong firm performance.

\author{
ARTICLE HISTORY \\ Received: 13-9-2021 \\ Revised: 12-10-2021 \\ Accepted: 12-11-2021

\section{KEYWORDS} \\ Diversification; \\ Competitive advantage; \\ Environmental turbulence; \\ Product market concept: \\ Ansoff growth matrix
}

\section{INTRODUCTION}

Diversification strategy might be more valuable and suitable when the company's product life cycle (PLC) is at the growth stage, which could be due to investment reasons and risk dispersion (Kotler, 1965; Levitt, 1965). During the growth stage, theoretically, companies' cash flows are in surplus; therefore, a strategic investment with calculated-risk and potential return trade-off is very much needed for a company's further growth. Thus, diversification strategy, following the Ansoff Growth Matrix $(1958,1965)$, is suitable for companies who are launching new products or targeting new markets to grasp opportunities following its familiarity, comprehensive marketing research, and when the Environmental Turbulence (ETurbulence) is at the level above three (Ansoff and Sullivan, 1993; Oroh, 2020).

Diversification is one of the most discussed topics in management literature, and both related and unrelated diversification studies show contradictory results toward firms' performance (Lee and Lee, 2007; Park and Jang, 2013). However, despite its definitions, arguments, pros and cons, prominent scholars showed that diversification is one of the key strategies to gain and sustain competitive advantage at the high turbulence and rapid technological change conditions (Ansoff, 1958; Teece et al., 1997; Teece, 2018). As competition is getting fiercer and challenging to predict, businesses in the future will be at high turbulence, and the only constant is rapid change, regardless of the industry. The good news is, theoretically, by focusing on a relevant diversification strategy, companies will avoid slack as one of the four threats on diminishing competitive advantage sustainability (Porter, 2007; materials used during classes at Harvard Business School - Executive Education in building and sustaining competitive advantage).

Distinguished scholars said that the fundamental of diversification concept and strategy is the concept of productmarket (Ansoff, 1958, 1965; Teece et al., 1997). Later, Ansoff extended the product-market concept in Ansoff-Growth Matrix $(1958,1965,1987)$, where he explored four strategies that companies should excel at to stay ahead of the competition. The four strategies are market penetration, market development, product development, and diversification. Both the academic world and industries agreed that all mentioned strategies are essential toward firm performance depending on the market situation and competition. The more attention and efforts toward applying these strategies the better the firm performance. This original concept has very much been mentioned but not deliberately cited by many, if not all, scholars in strategic management and strategic marketing. Thus, in order to be correct, not biased, and applied correctly in the real business, scholars might refer back to the original and fundamental concept of a diversification strategy, which is based on the product-market fundamental and then Ansoff Growth Matrix (Ansoff, 1958, 1965; Teece et al., 1997).

Product is the physical characteristics and performance of something tangible (offerings) produced, whereas the market is the target (mission) of the made product. Thus, according to this original fundamental, every product with a physical outlook and unique performance has its target (mission), not a general product for a common market. The activities to produce successful offerings are different from offering to offering and thus have different value chain models (Porter, 1985, 1996, 2008). Given this fundamental and changing market needs, not geographically but a change in people's needs, the company should adjust its product physical characteristics and performance to match the target (mission) and satisfy those changing needs. The following argument is that if every product has its target, product 
extension is a firm's activity to fulfil additional missions of the products following the extended needs of the clients, customers, or product-end users. Why are most people developing and focusing on diversification concepts contrary to this basic concept and not on the fundamentals? Even more problematic is that people are doing massive research based on a different fundamental. Is this a paralysis by analysis or misconception?

Interestingly, on the other part of the world called emerging countries, there is a tendency to claim and simplify a strategic paradigm such as innovation as "smart", but is an "imitation strategy" of existing matured products originally "manufactured" by the established companies at developed countries. The author believes that this trend might have no strategic ground following the Resource-based, Environment Serving Organization ESO-based, and Dynamic Capabilities-based activities, who claimed that resources and capabilities could not be only imitated regardless of the current products' performance to gain and sustain competitive advantage. On the contrary, this situation has given a strong signal to the industry leaders, and therefore, they can focus their attention and put more investment in technologies, which will sooner or later attack the said innovative product(s) with imitation strategy. Hence, a question can be raised whether this is a strategic movement from companies in emerging countries, a quick profit motive, or another strategic myopia.

\section{LITERATURE REVIEW}

Following the abovementioned scenario, distinguished scholars defined and mentioned diversification as one of the four interrelated strategies in the product-market growth matrix. It requires a rapid removal from the existing product line and present market, and therefore, it requires different skills, methods, and resources (Ansoff, 1958). Teece et al. (1997) exposed related diversification as the construct in the lead of existing capabilities. Hitt et al. (1997) used international diversification as the moderating variable to firm performance. Interestingly, not mentioning the resource-based view, Hsu and Liu (2008) discussed diversification as influencing current and existing competencies into new opportunities but sticking to the scope of the company's strategic resources and capabilities, consumer and geographic diversity. Ravichandran et al. (2009) explored this topic by applying information technology that may moderate the relationship between diversification and company performance and expose synergies. Anil and Yigit (2011) shared the related, and unrelated diversification and horizontal and vertical diversification to explore new businesses and opportunities and Li and Lo (2017) elaborated that there is a negative effect of top management teams' term to the international diversification and educational credentials diversity can reduce the negative effect. However, definitions provided by scholars are not enough to answer whether diversification strategy is still relevant and has a prominent role in today's digital economy. Industry practitioners usually look from the firm's internal capabilities, and therefore, perspectives to produce new offerings for customers with new missions require the firm's actions. Thus, the focus will be on the skills of the internal professionals and teams to create suitable offerings to satisfy the needs of the end-users.

Teece (1997) seemed to define a product almost similarly to Ansoff (1958). However, they have a different perspective on the market aspect that scholarly enriched its definition and scope. We can probably say that Ansoff (1958) is more descriptive and applicative on defining the market in the product-market concept as the mission of the created product, considering his background as a mathematician and company professional, while Teece (1997) is different. Teece is more mixed and intricate, with a resource-based view implicitly as the fundamental support. Another significant difference is the strategic concept. Teece (1997) explicitly said that a capability must be sharpened up to user needs (revenues source), unique (you can price your product as you wish without worrying about the competition), and should be difficult to imitate (take your profit, if not maintain and sustain it). This complements Ansoff's (1958) concept of aligning capabilities with environmental turbulence. The more turbulence or uncontrolled the environment, the more excellent capabilities needed to be built or acquired by companies to maintain and increase performance at all levels of turbulence.

Environmental turbulence in the Environment Serving Organization ESO-based concept focuses on the changes in the business environment that need to be carefully monitored and followed by adjusting the company's strategic aggressiveness and general management capability responsiveness to ensure its continued success and securing from any surprises. The turbulence level in the environment can be divided into five groups (Ansoff \& Sullivan, 1993) and then extended into six levels (Oroh, 2020). Focusing on turbulence with different levels from high certainty to high uncertainty and changes, it explicitly starts from stable-no change or slow change (Level One and Two) to incremental and predictable-fast change (Level Three and Four), into a surprising and deteriorating situation (Level Five and Six). Previous research has shown that indirectly, environmental turbulence as a mediating role has affected the significant relationship of strategic planning toward outstanding firm performance in the South East Asia automotive industry, especially in emerging countries (Oroh, 2018). This research supported previous research done at Vanderbilt University, which explored how strategic planning, despite its pros and cons, has been the dominant factor in supporting the best performance of American industries in the world for decades (Ansoff et al., 1970).

From a strategic management point of view, besides Barney and Peteraf's research in Resource-Based concepts (Barney, 1991, 2001; Peteraf, 1993, Peteraf and Barney, 2003), Wernerfelt is considered one of the strongest proponents of Resource-Based view. His explanation on the Resource-Product matrix (Wernerfelt, 1984, 1995) is the concept of the relative importance of resources in products (or products to resources) and focus more on developing and prioritising the company's resource in one market than to penetrate other markets. This is to establish and pursue becoming the leader in one strategic market before allocating resources to another market(s). Problems usually occur if the company is late in entering the potential market due to its rival's faster entry moves which will lessen its bargaining position in the market. Wernerfelt $(1984,1995)$ conducted his analysis through a resource-product matrix indicating the importance of a resource in a product (and vice versa). This matrix is a similar growth-share matrix model introduced by the Boston Consulting 
Group regardless of the weaknesses of the latter matrix. It can be implied that specific resources will provide the most valuable economics in gaining a competitive advantage in a particular market. However, most industry players are facing stable changes today, and they should have foreseen that this change and its pace will evolve faster and faster in the near future. Thus, the life-cycle of offerings (products) will get shorter, and anticipating this will enable companies to obtain a competitive advantage.

Interestingly, the resource-based opponents stated that strategic firms (established multinational companies) usually started with unique and precious resources and were able to obtain a competitive advantage. Although the said resources are also concurrently inimitable (difficult to be duplicated by rivals), not substitutable, and not transferable, those resources may produce a sustainable competitive advantage (Priem and Butler, 2021). Thus, the once scarcity and being precious is not enough to ensure competitive advantage. However, inimitability, nonsubstitutability, and nontransferability are essential but still cannot sustain and guarantee the sustainability of competitive advantage. Thus, it is helpful to explore the link between the Resource-Product concept (Wernerfelt matrix) and Product-Market concept (Ansoff Growth Matrix) to develop and enrich our fundamental thinking to establishing and maintaining the company's market(s) potentials to maintain above-average profit performance (Oroh, 2020).

The current world situation has shown that most companies, regardless of their excellent skills, regional operation areas, have high levels of surprising and deteriorating performance following the discontinuous turbulence in the business. Only a few companies in the advanced technology sector and pharmaceutical players are among the industries that gain the most in the current global deteriorating economic condition. This situation has given a strong signal that there are situations beyond the company's control, or higher turbulence levels in the industry have never occurred before. The ESObased scholars mentioned and proposed that the company's decision-makers or the chief executive officers should be aware and be more susceptible to every signal and situation at each turbulence level, as each must be treated differently with specific strategy (or combination of strategies), with adjustments of capabilities and relevant resources. In this current pandemic situation, a company that does not believe in investing in having advanced and suitable technological capabilities will face a challenging situation in the near future and adapt its company activities to the intense and different from the standard competition. Therefore, a firm needs to prepare its strategies and capabilities at all levels of turbulence to secure competitive performance, complementing the earlier mentioned product market concept and resource product concept.

Table 1. The extension of Matching Turbulence, Aggressiveness, and Responsiveness (Ansoff \& Sullivan, 1993; Oroh, 2020)

\begin{tabular}{|c|c|c|c|c|c|c|}
\hline Level & 1 & 2 & 3 & 4 & 5 & 6 \\
\hline $\begin{array}{l}\text { Environmental } \\
\text { Turbulence }\end{array}$ & $\begin{array}{c}\text { Repetitive } \\
\text { No } \\
\text { Change }\end{array}$ & $\begin{array}{l}\text { Expanding } \\
\text { Slow } \\
\text { Incremental } \\
\text { Change } \\
\end{array}$ & $\begin{array}{l}\text { Changing } \\
\text { Fast } \\
\text { Incremental } \\
\text { Change }\end{array}$ & $\begin{array}{c}\text { Discontinuous } \\
\text { Discontinuous } \\
\text { Predictable } \\
\text { Change } \\
\end{array}$ & $\begin{array}{c}\text { Surprising } \\
\text { Discontinuous } \\
\text { Unpredictable } \\
\text { Change }\end{array}$ & $\begin{array}{c}\text { Deteriorating } \\
\text { Change as a } \\
\text { stable variable }\end{array}$ \\
\hline $\begin{array}{c}\text { Strategic } \\
\text { Aggressiveness }\end{array}$ & $\begin{array}{c}\text { Stable } \\
\text { Stable } \\
\text { based on } \\
\text { Precedents }\end{array}$ & $\begin{array}{c}\text { Reactive } \\
\text { Incremental } \\
\text { change } \\
\text { based on } \\
\text { experience }\end{array}$ & $\begin{array}{l}\text { Anticipatory } \\
\text { Incremental } \\
\text { change based } \\
\text { on } \\
\text { extrapolation } \\
\text { (continuing } \\
\text { the trend) }\end{array}$ & $\begin{array}{c}\text { Entrepreneurial } \\
\text { Discontinuous } \\
\text { New Strategies } \\
\text { based on } \\
\text { observable } \\
\text { opportunities }\end{array}$ & $\begin{array}{c}\text { Creative } \\
\text { Discontinuous } \\
\text { Novel } \\
\text { Strategies } \\
\text { based on } \\
\text { creativity }\end{array}$ & $\begin{array}{c}\text { Creative } \\
\text { Entrepreneurial } \\
\text { Creating New } \\
\text { market, product } \\
\text { mission is based } \\
\text { on dynamic } \\
\text { capabilities } \\
\text { "technology as } \\
\text { the center" } \\
\text { (strategic } \\
\text { management of } \\
\text { technology) }\end{array}$ \\
\hline $\begin{array}{c}\text { Responsiveness } \\
\text { of } \\
\text { General } \\
\text { Management } \\
\text { Capability }\end{array}$ & $\begin{array}{l}\text { Stability } \\
\text { Seeking } \\
\text { Rejects } \\
\text { Change }\end{array}$ & $\begin{array}{l}\text { Efficiency } \\
\text { Driven } \\
\text { Adapts to } \\
\text { Change }\end{array}$ & $\begin{array}{l}\text { Market } \\
\text { Driven } \\
\text { Seeks } \\
\text { Familiar } \\
\text { Change }\end{array}$ & $\begin{array}{c}\text { Environment } \\
\text { Driven } \\
\text { Seeks Related } \\
\text { Change }\end{array}$ & $\begin{array}{l}\text { Environment } \\
\text { Creating } \\
\text { Seeks Novel } \\
\text { Change }\end{array}$ & $\begin{array}{c}\text { Environment } \\
\text { Changer } \\
\text { Sustains } \\
\text { Different } \\
\text { Changes with } \\
\text { unique } \\
\text { resources } \\
\text { (technologies) }\end{array}$ \\
\hline
\end{tabular}

Following the above argument and also research by scholars in Australia on the relationship between organisational performance and dynamic capabilities from the perspective of matching and creating market change (Kachouie, Mavondo \& Sands, 2018), the writer proposes to synthesise the concepts of "induced market turbulence"; namely the lobbying, change of market, change of market structure variables, and Environmental Turbulence (Ansoff \& Sullivan, 1993) into E-Turbulence level one and two (1-2), E-Turbulence level three and four (3-4), and E-Turbulence level five and six (5-6) 
respectively. Thus, Environmental Turbulence levels one and two will use the lobbying variable, which is relatively more stable. Environmental Turbulence levels three and four will stick to the change of market variable following its dynamic, and Environmental Turbulence level five and six will be represented by the change of market structure. These three groups' environmental turbulence levels will be explored further in this paper.

Researchers and management professionals must consider the quantitative measures of firm performance as the most crucial aspect and the qualitative side of the performance, as it is often shown that it needs to be put as one of the critical indicators. Financial performance indicators include, but are not limited to, Return on Invested Capital (ROIC), Return on Assets (ROA), and other tangible measures. Research in China showed that qualitative factors include the promptness of product modifications, speed of new product introduction, responsiveness to market changes, on-time delivery, lead time to fulfilling client's orders, and high level of customer service to major customers (Feng et al., 2013, and Flynn, et al., 2010) is very much applicable to measure companies' performance. Other scholars said that diversification could also be measured by analysing and calculating the related diversification variables and geographic diversification (Ravichandran et al., 2009).

From the above explanations, the author proposes the following hypotheses:

H1: Diversification has a positive relationship with firm performance

H2: Diversification has a positive relationship with Environmental Turbulence.

H3: Environmental turbulence level one and two has a mediating effect in the positive relationship between firm diversification and its performance level

H4: Environmental turbulence level three and four has a mediating effect in the positive relationship between firm diversification and its performance level

H5: Environmental turbulence levels five and six have a mediating effect in the positive relationship between firm diversification and its performance level

\section{METHODOLOGY AND SPSS RESULTS}

Following the above arguments and hypotheses, the writer is proposing the research model as follows:

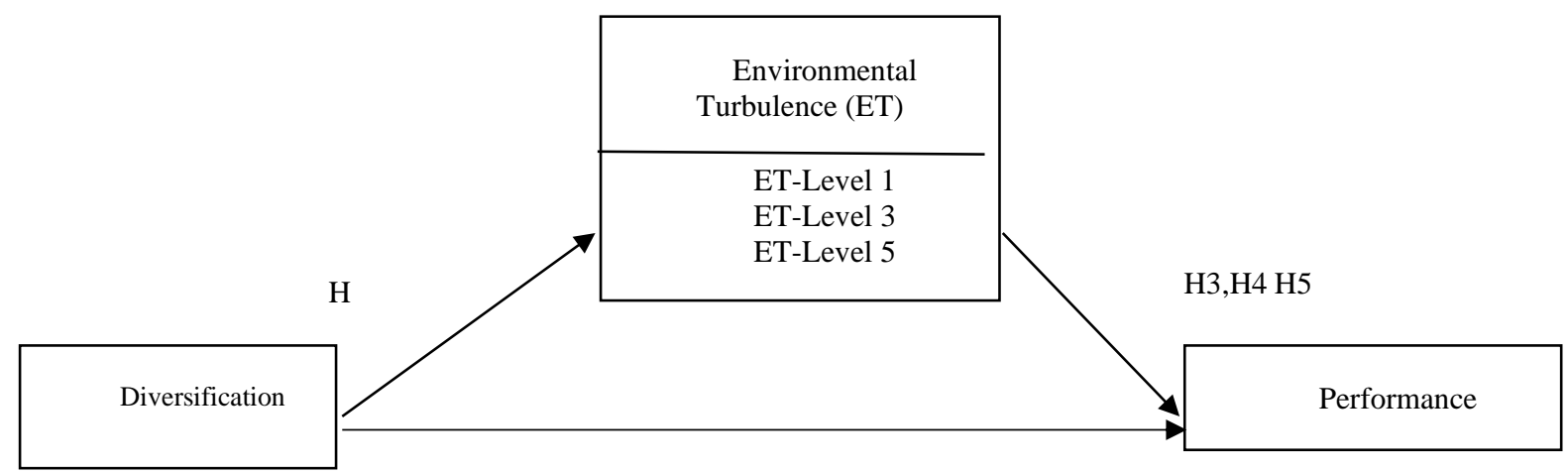

H1

Figure 1. Research Model

In order to collect answers from the respondents, the writer prepared questionnaires based on the original concepts of diversification, environmental turbulence, and company performance. Questionnaires were first tested to some senior executives and director's level to ensure that there will be no misunderstanding and misinterpretation to avoid wrong information prior to testing with IBM SPSS. Thus, respondents are not only firm executives but also internal professionals to sharpen the gathered information, increasing the quality and validity of this paper. After running the data and obtaining the first results, the writer shared the outcome with senior executives and directors to make them understand and advise them of the research managerial implications. Thus, this research combines qualitative and quantitative methods and will enhance the analysis results and can be applied immediately.

Following the quantitative research method and to run IBM SPSS, a Likert scale was used in the questionnaire from the scale of one (1) as "strongly disagree" to five (5) as "strongly agree". The questionnaires were sent to more than two hundred (200) top management, including the senior managers and directors of multinational companies in Indonesia. A pre-test interview was done prior to sending those questionnaires to ensure that the respondents provide accurate answers and responses. In addition, the writer used emails, social media, and phone calls during open discussions. Much research used the mediation model to prove the role of variables in the causal model relationship involving several independent variables and the dependent variable.

The writer used previous research models (Baron and Kenny, 1986; Hsu et al., 2008; Basu, 2014; Oroh, 2016, 2018; Kachouie et al., 2018) as well as their arguments to justify applying a mediation model and analysis in this paper to test particularly whether Environmental Turbulence has a mediating role or not, and which Environmental Turbulence Level is the mediator. Furthermore, supporting the method, current research using the mediation model shows that perceived 
learning mediates the relationship between reviewer mistakes and success experience toward customers' purchase intention. The perceived learning variable in mediating the reviewer success and mistake experience variable increases and decreases customers' purchase intention toward products and services (Reich \& Maglio, 2020). Other research using moderation and mediation model showed that anticipated feelings on the ethicality of production mediate the more vital link between consumers and productions toward purchase intentions (Paharia., 2020), and privacy concerns which mediate the relationship between revenue model and initial trust toward adoption intention in the start-up context (Baumbach et al., 2019).

Theoretically, in order to use a mediation model, several conditions should be met, including in this case: Diversification as the Independent variable must significantly predict the Dependent variable (Firm Performance); Diversification must significantly predict the Mediating variable (Environmental Turbulence) individually; Environmental Turbulence must significantly predict Firm Performance in the mediation model (Meyers, Gamst \& Guarino, 2013). To strengthen this argument, the writer also used other scholars' contentions who said that the use of multiple regressions to estimate a mediation model requires there to be no measurement error in the mediator and that the dependent variable (Firm Performance) should not have a causal relationship with the mediator (Baron \& Kenny, 1986). Since the results of IBM SPSS reflected the aforementioned condition, the writer was very much confident to continue and complete this research.

Furthermore, following previous research particularly and respectively by Basu (2014) and Kachouie et al. (2018), the writer used comparable method to measure the independent variable (diversification), mediating variable (Environmental Turbulence Level 1, Environmental Turbulence Level 3, and Environmental Turbulence Level 5), and dependent variable (Firm Performance). As mentioned above, the author then applied the method and research by Meyers et al. (2013) to calculate and analyse the mediating effects of Environmental Turbulence Levels on firm performance. Below are the results of Statistics Descriptive using IBM SPSS.

Table 2. The Analysis of Variance of Variables Relationship with Firm Performance

\begin{tabular}{lccccc}
\hline \multicolumn{1}{c}{ Model } & Df & $S S$ & $M S$ & $F$ & $P$ \\
\hline Regression & 4 & 0.513 & 0.128 & & \\
Residual & 85 & 1.773 & 0.021 & & \\
Total & 89 & 2.286 & & \\
\end{tabular}

Table 3. The Analysis of Variance of Independent Variable and Mediator (ETurbulence 3 and 4) Predicting the Outcome Variable (Firm Performance)

\begin{tabular}{ccccc}
\hline Model & $D f$ & $S S$ & $M S$ & $F$ \\
\hline Regression & 2 & 0.420 & 0.210 & 0.786 \\
Residual & 87 & 1.866 & 0.021 & \\
Total & 89 & 2.286 & & \\
\hline
\end{tabular}

Since the focus is on experienced company employees and professionals who can give more accurate answers, the respondents are senior managers and above levels. A total of ninety (90) respondents from various industries gave interesting feedback. Senior managers have at least ten years of related work experience in pulp and paper, mining, food and beverage, manufacturing, automotive, technology, plantation, insurance, and banking. Therefore, these diverse industries complement the research results since most senior managers who answered the questionnaires have extensive experience working at several industries prior to joining the current company. While directors, to support and strengthen the research, have more than 20 years of working experience and also lead-related divisions. 
Table 4. Respondents

Respondents Profile

\begin{tabular}{llcc} 
& Industry & Directors & Senior Managers \\
\hline 1 & Pulp \& Paper & 4 & 10 \\
2 & Mining & 4 & 6 \\
3 & Food \& Beverage & 3 & 6 \\
4 & Manufacture & 4 & 6 \\
5 & Automotive & 3 & 5 \\
6 & Technology & 3 & 7 \\
7 & Plantation & 3 & 7 \\
8 & Insurance & 3 & 6 \\
9 & Banking & 3 & 60 \\
\hline
\end{tabular}

By running the data using IBM SPSS and looking from Table 5 below, we can understand that the means of the data is shown to be more than 3.60 , which we can assume that most of the senior people in the industries agreed that their companies are basically in a good performance by executing and following the diversification and environmental turbulence that they recognised respectively. We can also explain from the data that most senior people recognised the role of diversification and that environmental turbulence levels three-four and five-six primarily affect their firm performance in general.

Table 5. Means and Standard Deviations as a Function of Variables in the Research Model

\begin{tabular}{llll}
\hline \multicolumn{1}{c}{ Variables } & $N$ & $M$ & $S D$ \\
\hline FirmPerformance & 90 & 3.8664 & 0.16027 \\
Diversification & 90 & 3.8562 & 0.34582 \\
ETurbulence 1-2 & 90 & 3.6156 & 0.38771 \\
ETurbulence 3-4 & 90 & 3.8511 & 0.38577 \\
ETurbulence 5-6 & 90 & 3.6333 & 0.32740 \\
\hline
\end{tabular}

Following the mediating process (Meyers et al.) to support this research (Figure 2 and Figure 3), we can say that statistically, we have achieved a significant amount of calculation on the research model to continue to analyse further. In the unmediated model (in this case, from diversification direct to Firm Performance), we can see it was .034 and increased to .059 , while in the mediated model, the corresponding standardised coefficients were .074 and .127. Because both these coefficients are statistically significant and because visual inspection informs us that the Path Coefficient is very much higher in the mediated model, we are guided to speculate that we have observed a partial mediation effect. Furthermore, following the mediating process (Meyers et.al.), we can use a series of steps (Appendix B) to test that speculation statistically. Continuing the mediating process, we can measure the relative strength of the mediating effect using the beta coefficients related to the paths in our mediation model. The strength of the indirect effect is the product of the beta coefficients related with paths Diversification to ETurbulence 3 and 4 and ETurbulence 3 and 4 to Firm Performance, which is equal to $(.125)^{*}(-.425)=0.053125$. The strength of the isolated direct effect is the beta coefficient in the unmediated model (value of .074), where diversification is the single predictor of firm performance. Thus, we can measure the relative strength of the mediated effect, which is equal to the indirect effect divided by the direct effect and equal to $0.053125 / 0.074=0.71790$. Therefore, we can conclude that about $71.79 \%$ of the effect of diversification on firm performance is mediated through ETurbulence 3 and 4. Following the results, the path model is shown below:

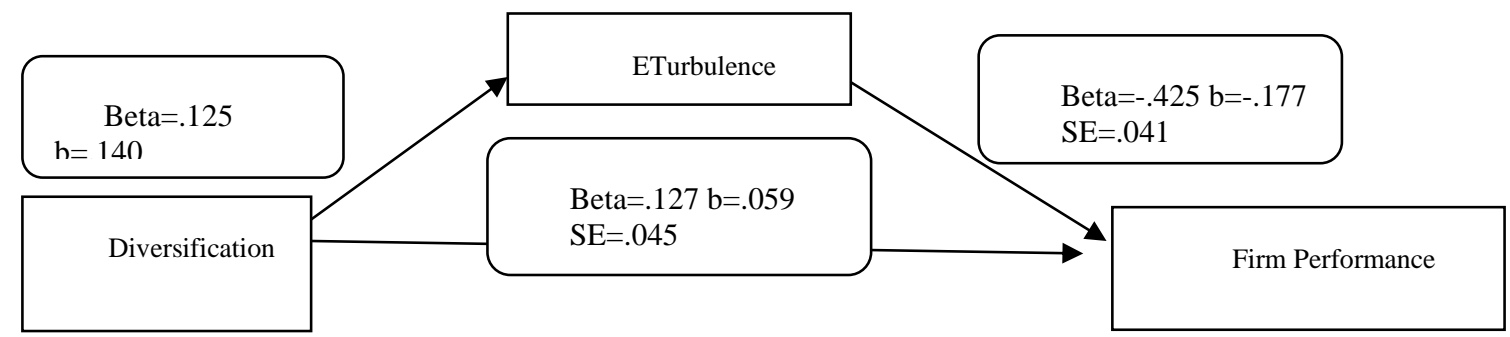

Figure 2. Results of the Path Model 
While the results of the unmediated model with diversification predicting firm performance are:

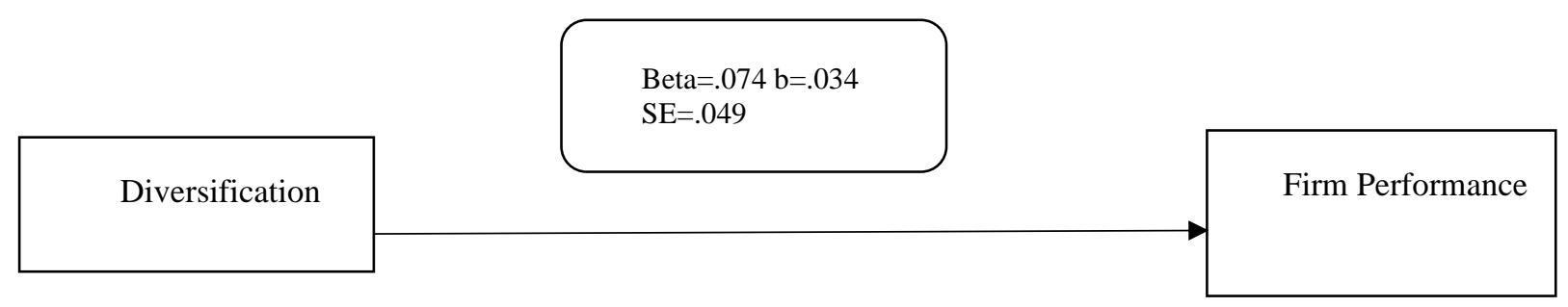

Figure 3. Results of the Unmediated Model

\section{CONCLUSION AND RECOMMENDATIONS}

The results show that diversification is indeed affecting both the firm performance and environmental turbulence variables. This has answered the first two hypotheses, and this supports further the Ansoff growth matrix. Hence, companies' diversification strategies should be positioned and executed correctly, and this action often should be synergised across functions and business units $(2+2=5$; Ansoff, 1965). Opportunities are always there since the company is full of information towards the market needs and ready to prepare relevant offerings with new missions. This is the mentality of the technology companies and what they have been doing to create this "digital" economic market (Environment Creator and Changer). This is also aligned with the Internet of Thing (IoT) that is to preserve an operating system that integrates a range of devices that communicate with each other and the user, and possibly with a virtual assistant such as Google Home, Alexa (Amazon), Siri (Apple), or Cortana (Microsoft) for example (Steenkamp, 2020).

The mediating variable, following the hypotheses, in this study and mainly the ETurbulence Level three and four, shows that this is the condition sine qua non that company has to understand and plan for proper actions to sustain performance. This result is supported and aligned with previous research at the automotive industry is one of the emerging countries (Oroh, 2018), which explained the role of Environmental Turbulence as a mediating role to support that strategic planning as an independent variable has a strong effect on best firm performance which was done in the United States as the largest economy in the world (Ansoff et al., 1970). For companies in emerging countries where competition has become painful and because of a market saturated in the "west", long-term preparation is mandatory. When we talk longterm, we mean groundwork of more than ten to even fifteen years in the company research and development division. Thus, best-performing companies in the aforementioned region should prepare what needs to be fulfilled in the next ten to fifteen years from today's market, including what technology will be needed and sustained and what new know-how should be developed today to anticipate the aforementioned next ten to fifteen years' needs, and also what resources the companies have to prepare in escalating the new technology development and invention. This is also aligned with current research that for multinational companies, it is crucial to design digital marketing strategies for emerging countries that are founded on a solid understanding of the differences in cross-cultural, socioeconomic, and privacy factors across countries that may influence the customer journey (Nam \& Kannan, 2020). Following the results that diversification is indeed affecting firm performance, a lesson from Apple products with advanced technology and capital intensive, including the current Amazon Web Services Cloud that is competing with Google and the other technology giants; Regional companies have no choice but to intentionally invest on developing new technology to produce "a user-friendly" and better offerings (products and services) for their existing loyal end-users and potential clients.

Furthermore, following Resource-based and ESO-based models, creating sufficient and strategic resources can be done by inventing new technology that will advance the company's position against competitors. However, this is challenging since financial centres are controlled mainly by existing multinational companies, and depending on them for financing will give a strong signal and counter implication. The question is how to overcome this unlikely condition. A real "strategy" game and self-financing strategy might be the solution. On the other hand, it is interesting to analyse how companies like Apple, Google, and Amazon manage their fat cash flow positions against their research and development budgets. It is not a surprise that maybe the best engineers and mathematicians in this world are all working in those companies. Since a long time ago, Ansoff mentioned that Apple is one of the companies aligning its business activities to all turbulence levels of the industry. They are ready to compete on all grounds, so companies need to follow their activities by strategically focusing on different products and missions where they are not in the industry and have a high barrier to entry. Level six of turbulence gives a clear direction for companies to focus on the environment (or create the environment or market) that puts them into a different position and level, and therefore, difficult to be followed and imitated. Each industry faces different kinds of competition and levels of intensities, requiring specific resources, aggressiveness, and capabilities.

Furthermore, this finding has supported the Ansoff Growth Matrix and the ESO-based concept besides the ResourceBased view and dynamic capabilities-based. Companies must align and adjust their strategic aggressiveness, capability responsiveness, and resources toward the Environmental Turbulence levels for companies to succeed. Companies that fail to prepare in advance for those six levels will face the worst performance. 
The finding shows that to succeed, companies should prepare themselves with excellent distinctive capabilities and specific resources following the market or economic situation. There is no single success formula, but clear strategic planning of any turbulence levels is again, and therefore, important for companies to take the lead and succeed. This research finding is interesting that by using the Ansoff-Growth Matrix, the Diversification Strategy, companies need to pay sufficient attention to the mediating variable "Environmental Turbulence level three and four", specifically to the critical indicators to affect increase the firm performance. By carefully examining all relevant indicators, the chance of success should be more significant and reduce the reluctance as the major concern on choosing diversification. This may also reduce the limitation of choosing and investing in aggressive diversification actions, regardless of related or unrelated, and pros and cons arguments. Therefore, further research is essential to analyse which indicators have vital roles in building firm efficacy.

Based on the research, the indicators of Environmental Turbulence Level three (3) and four (4) includes company activities that should regularly develop innovative new products to make customers reconsider their preferences, develop products that activate the unstated needs of customers, regularly adopt ideas from other industries to delight customers, set new product standards in the market, and as the organisation is the product leader, should be aware of competitors who will copy and follow their activities (Kachouie et al., 2018; Ansoff and Sullivan, 1993; Oroh, 2016, 2018, 2019, 2020).

For companies to have better performance, especially when deciding to implement a diversification strategy, they should consider planning those "indicators" strategically. It is time to plan accordingly and to satisfy the customers' needs. The pandemic is causing a huge surprise and turbulence for them and the overall industries, looking at the aforementioned companies. Their overall performances have been deteriorating to the bottom, which never happened before, and caused severe furlough and unemployment. Learning from this, particularly to diversification, the most logical part is that from now on, the environmental turbulence, especially at levels three (3) and four (4), will become one of the most important factors to be considered for preparing for, but this is again not enough. Following the ESO-based concept, companies have to prepare up to level five (5) and six (6) as well as level one (1) and two (2). These aspects should become the dominants and critical points in companies' annual planning and budgeting discussions and decisions. All companies will need to focus more on preparing offerings with the highest relevant technology to anticipate future higher turbulence.

\section{ACKNOWLEDGEMENT}

The author would like to thank UMP for supporting this paper to be published.

\section{REFERENCES}

Andreu, R., Claver, E., and Quer, D. (2010). Entry of Spanish tourism firms into new businesses, International Journal of Contemporary Hospitality Management Vol. 22 No. 1, 2010 pp. 7-23, Emerald Group Publishing Limited 09596119 DOI 10.1108/09596111011013444

Anila, I., and Yitba, I. (2011). The Relation between Diversification Strategy and Organisational Performance: A Research on Companies Registered to the Istanbul Stock Exchange Market, Procedia Social and Behavioral Sciences 24 (2011) 1494-1509

Ansoff, HI (1958). A Model of Diversification, Management Science 4(4):392-414

Ansoff, H. I., Avner, J., Brandenburg, R. G., Portner, F. E., and Radosevich, R., (1970). Does Planning Pay? The Effect of Planning on Success of Acquisitions in American Firms, Long Range Planning.

Ansoff, H. I. (1987). Strategic Management of Technology, Journal of Business Strategy, Vol. 7 Iss. 3 pp. 28 - 39

Ansoff, H. I. (1988). The New Corporate Strategy, John Wiley \& Sons, Inc., New York (From the original Corporate Strategy, 1965).

Ansoff, HI, and Edward, M.D. (1990). Implanting Strategic Management, 2nd Edition, Prentice Hall International, Cambridge, U.K.

Ansoff, HI, and Sullivan, P.A. (1993). Optimising Profitability in Turbulent Environments: A Formula for Strategic Success, Long Range Planning, Vol. 26, No. 5, pp. 11 to 23, Pergamon Press Ltd

Ansoff, H. I., (1994). Comment on Henry Mintzberg's Rethinking Strategic Planning, Long Range Planning, Vol. 27, No. 3.

Barney, J.B. (1991). Firm Resources and Sustained Competitive Advantage, Journal of Management 17, No. 1, 99-120

Barney, J.B. (2001). Is The Resource-Based "View" A Useful Perspective for Strategic Management Research? Yes, Academy of Management Review Vol. 26, No. 1, 41-56

Baron, R.M., and Kenny, D.A. (1986). The Moderator-Mediator Variable Distinction in Social Psychological Research: Conceptual, Strategic, and Statistical Considerations, Journal or Personality and Social Psychology, 1986, Vol.51, No.6, 1173-1182

Basu, S. (2014). Product Market Strategies and Innovation Types: Finding the Fit! Strategic Direction, Vol. 30 No. 3 , pp. 28-31, Emerald Group Publishing Limited, ISSN 0258-0543

Baumbach, E.K., Schuhmacher, M.C., Kuester, S., Kuharev, V. (2019). Making a first impression as a start-up: Strategies to overcome low initial trust perceptions in digital innovation adoption, International Journal of Research in Marketing 36 385-399 
Feng, T., Li, T., Sun, L., and Wang, D. (2013). External involvement and operational performance: The mediating role of internal integration, Chinese Management Studies Vol. 7 No. 3, 2013 pp. 488-507, Emerald Group Publishing Limited, 1750-614X DOI 10.1108/CMS-Feb-2012-0023.

Flynn, B.B., Huo, B., and Zhao, X. (2010). The impact of supply chain integration on performance: A contingency and configuration approach, Journal of Operations Management 28, 58-71

Hitt, M.A., Hoskisson, R.E., and Kim, H. (1997). International Diversification: Effects on Innovation and Firm Performance in Product Diversified Firms Author(s), The Academy of Management Journal, Vol. 40, No. 4, pp. 767-798 Published by: Academy of Management Journal

Hsu, C.W., and Liu, H.Y. (2008). Corporate Diversification and Firm Performance: The Moderating Role of Contractual Manufacturing Model, Asia Pacific Management Review 13 (1), 345-360.

Kachouie, R., Mavondo, F., and Sands, S. (2018). Dynamic Marketing Capabilities View on Creating Market Change, European Journal of Marketing, Vol. 52 No. 5/6, pp. 1007-1036, Emerald Publishing Limited 0309-056

Kerin, R. A., and Peterson R. A. (2013). Strategic Marketing Problems, Cases and Comments (13th Ed.) New Jersey: Pearson

Kotler, P. (1965). Phasing Out Weak Products, Solves an Often Unrecognised Problem, Harvard Business Review.

Lee, W., and Lee, N.S. (2007). Understanding Samsung's Diversification Strategy: The Case of Samsung Motors Inc., Long Range Planning 40 (2007) 488e504

Levitt, T. (1965). Exploit the Product Life Cycle, Harvard Business Review, Nov. - Dec.

Li, PY, and Lo, F.Y. (2017). Top Management Teams' Managerial Resources and International Diversification: The Evidence Under an Uncertain Environment, Management Decision Vol. 55 No. 9, pp. 1999-2017 (C) Emerald Publishing Limited 0025-1747 DOI 10.1108/MD-06-2016-0364

Meyers, L.S., Gamst, GC, and Guarion, A.J. (2013). Performing Data Analysis Using IBM SPSS, John Wiley \& Sons Inc., New Jersey.

Nam, H., and P.K. Kannan P.K. (2020). Digital Environment in Global Markets: Cross-Cultural Implications for Evolving Customer Journeys, Journal of International Marketing, 2020, Vol. 28(1) 28-47, American Marketing Association

Oroh, A.N. (2016). Does Synergy Mentality Mediate between Strategic Planning Relationship and a Firm's Performance? An Empirical Study of Manufacturing Companies in Indonesia, Pertanika J. Soc. Sci. \& Hum. 24 (S): 125 - 138, ISSN: 0128-7702 @ Universiti Putra Malaysia Press

Oroh, A.N. (2018). Does Environment-Serving-Organisation Concept Affect Firm Performance? A Strategic Perspective, Pertanika J. Soc. Sci. \& Hum. 26 (T): 239 - 252, ISSN: 0128-7702 () Universiti Putra Malaysia Press

Oroh, A. (2019). Does an Environment Serving Organization Based View Support A Product Market Strategy? A Firm Performance Analysis, WoMELA-GG 2019, January 26-28, Medan, Indonesia Copyright (C 2019 EAI (European Alliance for Innovation), DOI 10.4108/eai.26-1-2019.2282988

Oroh, A. (2020). Dynamic Capabilities-Based and Environment Serving Organisation-Based Concepts in Strategic Management: Are They Complementary? A Theoretical Overview" in 6th International Conference on Entrepreneurship (ICOEN) 2019, KnE Social Sciences, pages 88-103, DOI 10.18502/kks.v4i3.6381

Paharia, N. (2020). Who Receives Credit or Blame? The Effects of Made-to-Order Production on Responses to Unethical and Ethical Company Production Practices, Journal of Marketing, Vol. 84(1) 88-104, American Marketing Association

Park, K., and Jang, S. (2013). Effects of within-industry diversification and related diversification strategies on firm performance, International Journal of Hospitality Management 34 (2013) 51-60

Peteraf, M. A. (1993). The Cornerstones of Competitive Advantage: A Resource-Based View, Strategic Management Journal, Vol. 14, 179 - 191 (John Wiley \& Sons, Ltd.)

Peteraf, M. A., and Barney, J. B. (2003). Unraveling The Resource-Based Tangle, Managerial and Decision Economics 24, pp 309 - 323, (John Wiley \& Sons, Ltd.)

Porter, M. (1985). Competitive Advantage, Creating and Sustaining Superior Performance, The Free Press, New York.

Porter, M. (1996). What Is Strategy, Harvard Business Review, Reprint 96608, by the President and Fellows of Harvard College

Porter, M. (2008). On Competition, Updated and Expanded Edition, Harvard Business School Publishing Corporation, Boston, MA 02163.

Priem, R.L., and Butler, J.E. (2001). Is the Resource-Based "View" a Useful Perspective for Strategic Management Research? Author(s): Richard L. Priem and John E. Butler Source: The Academy of Management Review, Vol. 26, No. 1, pp. 22-40 Published by: Academy of Management

Ravichandran, T., Liu, Y., Han, S., and Hasan, I. (2009). Diversification and Firm Performance: Exploring the Moderating Effects of Information Technology Spending, Journal of Management Information Systems, 25: 4, $205-240$.

Reich, T., and Maglio, S.J. (2020). Featuring Mistakes: The Persuasive Impact of Purchase Mistakes in Online Reviews, Journal of Marketing, Vol. 84(1) 52-65, American Marketing Association

Schmitz, C., Friess, M., Alavi, S., and Habel, J. (2020). Understanding the Impact of Relationship Disruptions, Journal of Marketing, Vol. 84(1) 66-87, American Marketing Association

Steenkamp, J. (2020). Global Brand Building and Management in the Digital Age, Journal of International Marketing, Vol. 28(1) 13-27, American Marketing Association

Teece, D.J., Pisano, G., and Shuen, A. (1997). Dynamic Capabilities and Strategic Management, Strategic Management Journal, Vol. 18, No. 7. (Aug., 1997), pp. 509-533. 
Teece, DJ (2018). Business Model and Dynamic Capabilities, Long Range Planning, 51, 40-49.

Wernerfelt, B. (1984). A Resource-Based View of the Firm, Strategic Management Journal, Vol. 5, No. 2, pp. 171-180

Wernerfelt, B. (1995). The Resource-Based View Of The Firm: Ten Years Later, Strategic Management Journal, Vol. 16 No.3, 171-174

\section{CONFLICT OF INTEREST}

The author, as noted, certify that he has NO affiliations with or involvement in any organisation or agency with any financial interest (such as honoraria; educational grants; participation in speakers' bureaus; membership, jobs, consultancies, stock ownership, or other equity interest; and expert testimony or patent-licensing arrangements), or nonfinancial interest (such as personal or professional relationships, affiliations, expertise or beliefs) in the subject matter or materials addressed in this manuscript.

\section{AUTHORS' BIOGRAPHY}

\section{Author Professional Picture}

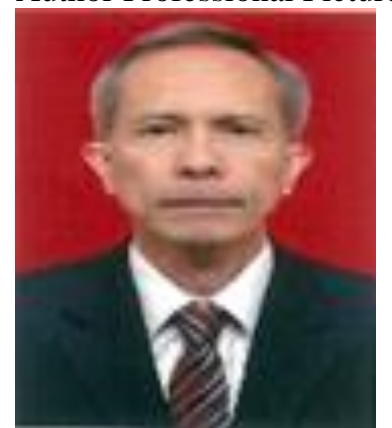

Dr. Augustinus Nicolaas Hillebrandes Oroh MBA

Nicolaas.oroh@ciputra.ac.id

Nicoroh@yahoo.com

He is an industry practitioner and professional in the Higher Education Services with education background as follows: Doctor/Ph.D. degree in Strategic Management, Parahyangan Catholic University (Distinction), MBA degree in Strategic Management at The Igor Ansoff School of Strategic management, US International University (AIU), San Diego, California, USA, (Minor subject in Corporate Finance), and Advance Certificate from Harvard Business School, Soldiers Field, Boston, Massachusetts, USA, at Executive Education Program in Strategy.

His research papers are in strategic management and strategic marketing topics, and published at International Journals. Currently working and writing papers in strategic marketing and management topics. He is a Visiting Senior Lecturer in strategic management at Queensland University of Technology QUT-Business School, Brisbane, Australia, and Visiting Senior Lecturer in Leadership and Marketing at NHL-Stenden University, Holland. He spent most of his time in the industry with more than 30 years as a professional, working in Multinational companies (MNC) as senior managers and directors in industries including Food \& Beverage, Pulp \& Paper, and Coal Mining.

Previously he was working at Binus Business School (AACSB Accredited) in Jakarta, and currently at the School of Business and Management at Ciputra University in Surabaya (2019-present) as the Head of Undergraduate Program in International Business Management - International Class 